\title{
MENGEMBANGKAN PENDIDIKAN BERWAWASAN KEUMMATAN
}

\section{Rosniati Hakim}

Dosen Fakultas Tarbiyah IAIN Imam Bonjol Padang

Jl. Prof. M. Yunus Lb. Lintah Padang 35711

Email: rosniati_hakim@yahoo.com

\section{ABSTRAK}

Tulisan ini bermaksud mendiskusikan sejumlah kemungkinan bahwa pendidikan Islam itu memerlukan aturan hidup sebagaimana digariskan al-Qur'an. Ia harus mengembangkan nilai-nilai moral sebagai tema sentralnya. Metode yang digunakan dalam tulisan ini adalah analisis wacana. Wacana ummah yang dalam ilmu sosial disebut dengan kemasyarakatan dianalisis melalui pendidikan Islam sehingga menghasilkan konsep pendidikan berwawasan keumatan. Isinya, bahwa setiap pendidik setidaknya memerlukan tiga syarat yang wajid dipenuhi untuk mempersiapkan peserta didik meraih kedudukan sebaik-baiknya umat (khairu ummah), yaitu amar makruf, nahi mungkar dan persatuan dalam berpegang teguh kepada ajaran Allah. Tujuan pendidikan yang diharapkan adalah agar memperoleh petunjuk, kemenangan (falâh), dan terhindar dari siksa. Metode yang digunakan melalui sejumlah pembuktian/argumentasi, kisah, hikmah, man'ǐ̌hah, mujâdilah, syûra dan ishlâh. Pendidik adalah panutan dalam bidang ilmu dan amal. Peserta didiknya adalah manusia baik sebagai individu maupun kelompok.

Kata Kunci: Pendidikan Islam, Ummah, Kemasyarakatan

\section{ABSTRACT}

This paper discusses the possibilities that Islamic Education needs life system as stated in the Holy Koran. This life system must consist of moral as the central theme. The method used in this study was discourse analysis. The term "ummab" which is social study is known as "kemasyarakatan (social life)" was analyzed through Islamic education so that it results in education conception with social conception. It consists of the issue that every educator needs at least three requirements that must be fulfilled in order to prepare learners to be able to achieve the position as the best people (khairu ummab): amar makruf, nabi munkar, and commitment to be loyal to Allah's rules. The objective of the education expected to get the guidance, victory (falab), and save from the torments. The method used was through providing evidences/ arguments, stories, wisdom, man'izhah, mujadilah, syufa and ishlah. The educator is the role model in the field and action. Learners are the best people as individual and group.

Keywords: Islamic Education, Ummah, Social Life 


\section{PENDAHULUAN}

Al-Qur'an dan Sunnah Rasulullah Saw. Di samping memberikan petunjuk tentang iman dan ibadah, juga mengajarkan tentang hubungan manusia dengan sesamanya, baik dalam konteks keluarga, masyarakat maupun negara. Allah SWT berfirman "Mereka diliputi kehinaan di mana saja mereka berada, kecuali jika mereka berpegang pada tali (agama) Allah dan tali (perjanjian) dengan manusia..."(Q.S Ali Imran; [3]: 112), dan manusia harus menjaga hubungan tersebut (Q.S. al-Baqarah [2]: 83, dan Luqman [31]: 18-19).

Tujuan utama al-Qur'an adalah menegakkan sebuah tatanan masyarakat yang adil, berdasarkan etika, sehingga dapat bertahan di muka bumi ini. Individu dan masyarakat tidak dapat dipisahkan, karena tidak ada individu yang hidup tanpa masyarakat. Konsep-konsep amal perbuatan manusia, terutama taqwa, hanya akan memiliki arti di dalam sebuah konteks sosial (masyarakat), yang sarat dengan nilai-nilai pendidikan. Berkenaan dengan ini, Al-Syaibany (1975: 164) mengungkapkan bahwa di samping masyarakat merupakan arena tempat berlangsungnya proses pendidikan, masyarakat itu sendiri juga merupakan satu faktor pokok yang memengaruhi pendidikan.

Al-Qur'an mempunyai pendirian yang tegas, bahwa setiap masyarakat atau bangsa akan memperoleh haknya sesuai dengan usahanya sendiri (QS. an-Nisa' [4]: 170). Allah tidak akan menghancurkan negeri-negeri (kebudayaankebudayaan atau bangsa-bangsa) secara aniaya selagi warganya aktif di dalam kebajikan (Q.S Hud [11]: 117). Al-Qur'an adalah kitab suci yang mengandung pendidikan, risalah yang jelas dan nasehat yang logis serta cara-cara bermu'amalah (bergaul) secara baik (Fayed, 1409 H/1989 M: 7). Semua ayatnya merupakan materi pendidikan yang harus diketahui dan dipelajari oleh setiap orang yang mengaku dirinya beriman. Salah satu bidang garapan ilmu pendidikan adalah pendidikan masyarakat/pendidikan sosial/pendidikan luar sekolah.

Tulisan ini bermaksud mendiskusikan materi pendidikan sosial dan kemasyarakatan dalam perspektif pendidikan Islam. Metode yang digunakan adalah analisis konten. Metode tersebut digunakan untuk menganalisis sejumlah ayat yang terdapat dalam al-Qur'an yang relevan dengan pendidikan sosial dan/atau kemasyarakatan, di antaranya adalah pengertian pendidikan kemasyarakatan, konsep masyarakat dalam al-Qur'an, ciri-ciri masyarakat Islam, implementasi pendidikan kemasyarakatan (pada acuan normatif yang digariskan al-Qur'an, sebagai sumber yang paling utama untuk melihat rangkaian pembelajaran berupa ajakan, suruhan, larangan, tindakan, teguran, pujian, ancaman, harapan dan hinaan).

\section{PEMBAHASAN}

Dalam pengertian sehari-hari, masyarakat berarti, sekelompok manusia yang hidup dan mempunyai hubungan antara yang satu dengan yang lainnya di satu daerah (Kusumamihardja, dkk, 1985: 253-254). Namun pengertian yang lebih sederhana dikemukakan oleh Al Syaibany (1975: 165), bahwa masyarakat 
adalah kumpulan individu dan kelompok yang diikat oleh kesatuan Negara, kebudayaan dan agama. Di dalamnya termasuk jalinan hubungan timbal balik, kepentingan bersama, adat kebiasaan, pola-pola, teknik-teknik, sistem hidup, undang-undang, institusi dan segala segi/fenomena kehidupan.

Kedua pendapat di atas memberikan pemahaman, bahwa sebenarnya kehidupan manusia itu bersifat kemasyarakatan (makhluk sosial). Artinya bahwa secara fitri, manusia itu bersifat kemasyarakatan. Di satu pihak, kebutuhan, keuntungan, kepuasan, karya dan kegiatan manusia, pada hakikatnya bersifat kemasyarakatan di pihak lain, gagasan-gagasan, idealisasi-idealisasi, perangaiperangai serta kebiasaan-kebiasaan khas manusia melekat pada individu. Dengan memberi manusia satu kesatuan rasa maka sistem kemasyarakatan yang dimilikinya tetap ada selama ada pembagian kerja atau aturan, dan rasa saling membutuhkan dalam suatu perangkat, tradisi dan sistem tertentu. Dengan kata lain, masyarakat merupakan suatu kelompok manusia yang berada di bawah tekanan serangkaian kebutuhan, seperangkat kepercayaan, idealisasi dan tujuan yang tersatukan dan lebur dalam satu rangkaian kesatuan kehidupan bersama (Soekanto, 1995: 187). Bila dihubungkan dengan pendidikan, maka segala pengalaman yang berlangsung dalam lingkungan dan sepanjang hidup bersama, dengan berbagai keterikatannya itu, dapat dikatakan sebagai pendidikan kemasyarakatan.

Soejono (1980: 23-24) mengemukakan bahwa, pendidikan kemasyarakatan itu adalah tindakan atau pendidikan yang pada pokoknya menanamkan pengertian, pengetahuan, dan keinsyafan, bahwa setiap orang tentu hidup dalam suatu kelompok. Di dalamnya, manusia memupuk diri dengan rasa senang pada kehidupan masyarakat yang penuh dengan peraturan dan tujuan mulia. Dalam hidup bermasyarakat diperlukan suatu bimbingan dan kemauan kuat serta sikap yang tepat untuk berbuat demi kehidupan bersama dan tidak berbuat hal-hal yang merugikan kebahagiaan hidup bersama/sosial.

Seseorang cenderung mau berbuat bila ia mengetahui dan memahami serta menginsyafi, bahwa hidup bersama itu sangat berarti dalam mencapai tujuan hidup sebenarnya. Pada dasarnya pembentukan kepribadian yang utuh dari akal, jiwa dan tubuh merupakan tujuan inti dalam pendidikan (Abdullah, 1990: 148). Islam meyakini bahwa tujuan penciptaan manusia oleh Tuhan sebagai perwujudan kehendak-Nya, dan bagian tertinggi dari tujuan itu adalah moral (akhlak), yakni kepribadian utama, sebagaimana yang dimaksud dalam tujuan pendidikan Islam.

Menurut Ismail R. Al-Faruqi (1994: 172) Islam memandang masyarakat sebagai pranata Ilahi, suatu pola Allah, yang diperlukan manusia untuk memenuhi tujuan penciptaannya sebagai hamba atau pengabdi. Oleh karena itu lanjut $\mathrm{Al}$ Faruqi, masyarakat sangat memerlukan perangkat/metode dalam memperoleh pengetahuan (QS. al Hujurat [49]: 6). Sebaliknya, masyarakat sangat diperlukan oleh moral dan sejarah sebagai panggung pengejawantahan moral. Sebagai suatu pola Allah, tujuan pendidikan-Nya (al-Qur'an) adalah membina 
manusia secara pribadi dan kelompok sehingga mampu menjalankan fungsinya sebagai hamba Allah dan khalifah-Nya. Hal ini menunjukkan bahwa dalam membangun peradaban dunia ini harusnya sesuai dengan konsep yang ditetapkan Allah, yakni bertakwa kepada-Nya (Shihab, 1994: 172).

Dari paparan di atas, dapat dipahami bahwa pendidikan kemasyarakatan di samping berhadapan dengan sekelompok orang, juga memelihara aktivitas dan aturan secara timbal balik. Paradoks ini sangat penting bagi sejarah manusia sehingga telah mencatat, bahwa melalui al-Qur'an, Nabi Muhammad Saw telah berhasil membangun dan membina sebuah masyarakat dengan mendirikan sebuah masjid, sebagai media konsolidasi intern umat Islam. Kemudian, Nabi menyatukan kaum Muhajirin dan Anshar dengan menciptakan persaudaraan di antara mereka. Langkah selanjutnya, Nabi membangun konsolidasi antar umat Islam dan non muslim dengan cara membuat perjanjian bersama yang kemudian dikenal dengan Piagam Madinah (Pulungan, 1994: 63).

\section{Ciri-ciri Masyarakat Islam}

Masyarakat Islam mempunyai sikap dan cirinya sendiri yang khas dan berbeda dengan masyarakat lain. Masyarakat Islam benar-benar menjadi masyarakat ideal dan menjadi contoh manusia sejagat dalam meraih kebahagian, kemakmuran dan memenuhi kebutuhan baik rohani maupun jasmani. Masyarakat yang diidamkan dan yang hendak dibina oleh Islam bukan merupakan satu idaman yang khayali atau terlalu ideal hingga tidak dicapai dalam realitas. Masyarakat Islam adalah suatu gambaran masyarakat yang merangkum idealisme dan realisme, yakni masyarakat yang mengimbangi tuntutan dunia dan akhirat, pembinaan fisik, akal dan rohani. Ia mengimbangi tuntutan pribadi dan orang banyak. Masyarakat tersebut pernah dijelmakan di suatu zaman dahulu, ketika berkembangnya dakwah Islam, dan pada zaman kegemilangan negara Islam. Kesannya telah dirasakan; ia berupa kebahagiaan, kemakmuran, kemuliaan, maruah, keadilan, kewarasan yang berkembang dan terkontrol; membawa kebahagiaan pada semua insan.

Masyarakat yang benar-benar boleh dianggap masyarakat Islam ialah masyarakat yang menerapkan Islam dalam aspek akidah, ibadah, akhlak, undangundang dan sistem Islam. Ia adalah masyarakat yang mentauhidkan Allah dalam akidah dan ibadah. Kekuasaan mutlak yang memerintah terserah kepada ketentuan Allah, agama, akhlak, ilmu namun demikian kemuliaan diri insan dan institusi keluarga cukup diberikan perhatian. Proses pembangunan pesat, kerja dan harta dinilai sewajarnya dan dijadikan sebagai harta yang punya fungsi sosial. Kekuasaan atau kekuatan dihormati dan di atasi oleh prinsip agama, akhlak dan budi luhur. Di dalamnya digalakan sifat toleransi dan terbuka untuk menerima arus kemajuan atau nilai kebudayaan dari luar yang tidak menggugat ciri kepribadian dan nilai kebudayaan masyarakat muslim. Segala yang menghasilkan perpaduan, solidaritas dan kerjasama antara anggota masyarakat Islam dikerahkan semaksimal mungkin. Pendek kata, segala ciri dan nilai yang mesti 
dipunyai oleh masyarakat Islam itu dihormati dan dijaga. Ciri-ciri masyarakat Islam yang dimaksud yaitu;

1. Tauhid dijadikan sebagai fondasi karena masyarakat Islam pada dasarnya terwujud di atas pondasi iman. Islam merobohkan syirik sosial. Tauhid menyatukan orang-orang yang menerimanya dalam satu ikatan yang menyamaratakan hak dan tanggung jawab semua insan. "Tidak ada Tuhan selain Allah." (QS. Muhammad [47]: 19). "Tika kamu mencintai Allah, ikutilah aku, niscaya Allah mencintaimu.” (QS. Ali 'Imran [3]: 31).

2. Agama diletakan pada posisi tertinggi. Segala urusan hidup dikembalikan kepada hukumnya sesuai dengan ayat al-Qur'an yang menyerukan bahwa pertikaian supaya dikembalikan kepada putusan Allah dan Rasul. Artinya umatnya selalu merujuk kepada prinsip dan dasar yang dikandung oleh ajaran Allah dan Rasulnya. "Tika berbeda pendapat tentang sesuatu, maka hendaklah dikembalikan kepada Allah dan Rasul-Nya.” (QS. An-Nisa' [4]: 59).

3. Akhlak dijadikan sebagai sendi pertama dalam kehidupan. Masyarakat Islam ialah akhlak mulia, berperilaku sopan dan santun serta senantiasa menegakkan keluhuran budi pekerti dengan cara-cara yang juga harus utama. Oleh sebab itulah Rasulullah SAW bersabda, "Aku diutus untuk menyempurnakan kemuliaan akblak". Bangunan akhlak yang kokoh dirintis oleh nabi kemudian dijadikan landasan banyak peradaban umat manusia sehingga menjadi tinggi dan maju. Oleh karena itu, akhlak juga merupakan tujuan terakhir dari kehidupan manusia. Tuhan menciptakan mati dan hidup, untuk menguji manusia, siapa di antara manusia yang lebih baik amalnya maka merekalah yang untung (QS. al Mulk [67]: 2) dan (QS. Hud [11]: 7 dan 116; al Ambiya' [21]: 13; al-Mukminun [23]: 33 dan 64).

4. Ilmu diperlakukan sebagai penerang umat. Ilmu yang benar adalah ilmu yang bertujuan memantapkan akidah dan agama Islam. Ilmu adalah salah satu persyaratan dalam melaksanakan tugas manusia sebagai khalifah di muka bumi. "Tidak sepatutnya semua mukmin pergi ke medan perang, mengapa sebagian tidak pergi untuk memperdalam pengetahuan agama." (QS. al-Taubah [9]: 122), dan pengajaran dari Allah SWT kepada nabi-Nya untuk berdo'a: "Ya Tubanku, tambabkanlah ilmu kepadaku.” (QS. Thaha [20]: 114).

5. Kehormatan manusia adalah segalanya bagi orang Islam. Masyarakat Islam tidak boleh bermusuhan, berpisah diri karena perbedaan warna, bangsa, agama, harta atau keturunan. Masyarakat Islam adalah masyarakat yang menempatkan bahwa hidup aman, bebas, membina keluarga dan memelihara anak dengan baik sebagai ajaran sosial yang utama. 
6. Institusi keluarga merupakan unsur terkecil yang harus dibina dan dijaga pertama kali bahkan dari api neraka. Wanita dipandang sebagai benteng terakhir yang mempertahankan norma masyarakat dan keluarga. Hubungan kekeluargaan dibina di atas tunas-tunas yang luhur, kebenaran, keadilan dan kasih sayang. Allah menciptakan pasangan-pasangan untukmu, agar kamu merasa tentram dan menumbuhkan di antara kalian rasa kasih dan sayang (QS. al-Rum [30]: 21).

7. Masyarakat Islam adalah masyarakat yang dinamik. Allah tidak akan mengubah keadaan suatu kaum sebelum mereka mengubah keadaan diri mereka sendiri (QS. al-Ra'du [13]: 11 dan al-Anfal [8]: 53).

8. Masyarakat Islam adalah masyarakat kerja. Kerja merupakan hak, kewajiban dan tanggung jawab manusia. Manusia bebas menentukan jenis pekerjaaan yang hendak dijalankan olehnya sebagai mata pencarian, selagi halal dan berada di dalam norma-norma agama. Allah SWT memudahkan bumi untuk dijelajahi oleh manusia, maka jelajahilah hingga ke segala penjuru dan makanlah sebagian dari rezekiNya (QS. al-Mulk [67]: 15).

9. Dalam masyarakat Islam, nilai dan peranan harta hak milik diperhitungkan untuk menjaga kehormatan manusia dan membangun masyarakat madani. Pemilik harta pada hakikatknya, dalam pengertian yang paling luas, ialah Allah SWT. Oleh karena itu, hak milik pribadi, seperti harta yang diperoleh dari mata pencaharian hendaknya disalurkan karena ridha Allah sesuai dengan syari'at. Harta tidak boleh ditumpuk dan ditimbun tetapi digerakan untuk kepentingan masyarakat. Tunaikanlah kewajiban mencari nafkah berdasarkan hak dan kewajibannya (QS. al- Hadid [57]: 3, Saba' [34]: 39, al-Taubah [9]: 34, dan Ali-Imran [3]: 97)

10. Masyarakat Islam adalah masyarakat yang terbuka, yakni bisa menerima pengaruh baik ilmu pengetahuannya dari masyarakat lain. Namun dalam interaksinya tidak boleh menghilangkan identitas keIslamannya.

11. Masyarakat Islam bersifat insaniyah, saling mengasihi, menolong dan membantu di antara satu dengan yang lainnya. Insaniyah adalah sebentuk tindakan saling menasehati, mengajak berbuat kebajikan dan mencegah kemunkaran secara terpadu dan solid (QS. al-Taubah [9]: 71).

Beberapa ciri masyarakat Islam di atas merupakan tujuan yang harus dicapai melalui penjelmaan nilai-nilai yang mengatur masyarakat Islam, yang telah dilestarikan oleh al-Qur'an dalam konsep "falâh”, sebagaimana tercantum dalam surat Ali Imran [3]: 104 dan 130, surat al-Hasyr: [59]: 9, dan al-Jumu'ah [62]: 10, yaitu kesejahteraan (kebahagiaan) yang dengan jelas hubungkan dengan 
masyarakat maupun individu (QS. al-A'la [87]: 14), kemudian menuju kesejahteraan kolektif (bersama) yang disajikan dalam semua dimensi.

Muhammad Fazlur Rahman Ansari (1983: 173) menyebutkan bahwa ada 21 dimensi pokok yang muncul dalam masyarakat, sebagai misi al-Qur'an untuk dijelmakan ke dalam masyarakat, sebagaimana telah dicontohkan oleh Nabi Muhammad Saw pada masyarakat Islam yang lahir dari beliau. Dimensi yang dimaksud adalah masyarakat mulia (QS. [33]: 44, [15]: 72, [17]: 23, [89]: 17, [69]: 17), masyarakat yang adil di bidang sosial, ekonomi (QS. [49]: 13), masryarakat seutuhnya, masyarakat yang seimbang, ideal, dinamis, progresif, kreatif (QS. [23]: 14), demokratis (QS. [9]: 60), welas asih (QS. [17]: 24, [30]: 21, [48]: 29, [90]: 17), mementingkan orang lain (QS. [59]: 9), terpelajar (QS. [58]: 11), disiplin (QS. [24]: $51 \mathrm{dst}$ ), persaudaraan (QS. [49]: 10), manusiawi (QS. [60]: 8-9), industrif (QS. [53]: 39, [59]: $18 \mathrm{dst}$ ), dan sederhana (QS. [11]: 77).

\section{Konsep Masyarakat dalam Al-Qurân}

Dalam kamus Bahasa Arab terdapat kata "al-musyârakah" (Al-Munawwir; 1984: 765) yang berarti "perserikatan". Konsep "perserikatan" sama dengan perkumpulan, ikatan dan perhimpunan. Istilah ini memang sangat erat hubungannya dengan kemasyarakatan. Menurut Muthahari (1992: 40-41), ada dua jenis istilah kemasyarakatan yang digunakan dalam al-Qur'an, sebagian berhubungan dengan suatu gejala tertentu tentang kemasyarakatan, seperti: millah (komunitas), syari'ab (hukum Allah), syar'ab (jalan), minhaj (metode), dan sunnab (tradisi). Istilah-istilah ini tidak relevan dengan pembahasan ini, tetapi sejumlah istilah yang merujuk ke semua atau ke sebagian kelompok manusia dapat dipertimbangkan untuk mengetahui pandangan al-Qur'an tentang kemasyarakatan. Kata-kata yang dapat dirujuk tersebut adalah: qaum (kaum), ummah (komunitas), nas (umat manusia), qaba-il (suku-suku), rasul (utusan), nabi (nabi), imam (pemimpin), wali (wali), mukmin (orang beriman), kafir, munafiq, musyrik, mudzabdzab (orang ragu-ragu), mubajir (yang berhijrah), mujabid (pejuang), shadiq (yang benar), syahid (saksi), muttaqi (yang takwa), shalih (yang salih), mushlib (pembantu), mufsid (perusak), amir bil ma'ruf (yang memerintah agar orang mematuhi perintah Allah), nabi anil mungkar (pencegah kemungkaran), 'alim (bepengetahuan), nashih (pemberi nasehat), rabbani (Ilahi), rabbi (rabbi), kabin (pendeta), rubban (rahib), 'ali (tinggi), musmusta'li (unggul), mustakbir (tiran,sombong), mustadh'af (tertindas, terzalimi), musrif (pemboros), mutraf (bergelimpangan), thaghut ( berhala), muluk (raja-raja), ghany (orang kaya), faqir (fakir, orang-orang miskin), mamlik (yang diperintah, dikuasai), malik (pemilik, tuan), hurr (bebas, merdeka), dan 'abd (abdi, budak).

Sebagian istilah di atas seperti: mushalli (yang shalat), mukhlis (yang ikhlas, tulus), shadiq (setia, sejati), munfiq (yang dermawan), mustaghfir (yang meminta ampun kepada Allah), ta'ib (yang bertaubat), dan hamid (yang memuji) digunakan hanya untuk menggambarkan jenis-jenis perilaku, bukan untuk merujuk ke kelompok-kelompok masyarakat tertentu. Oleh karena itu, penting untuk 
mempelajari arti tambahan dan makna ayat-ayat yang menggunakan istilah-istilah yang dirujuk sebelumnya, terutama kata-kata yang berhubungan dengan konsep masyarakat. Dengan demikian, cukup banyaknya istilah yang berhubungan dengan "kemasyarakatan" dalam al-Qur'an. Agar lebih fokus maka pembahasan dibatasi pada kata ummah. Bila diperlukan, akan ditelaah arti tambahan dan makna ayat yang menggunakan istilah-istilah yang dirujuk sebelum dan sesudahnya. Ummah adalah kata berbentuk tunggal, dan umam adalah bentuk jama'nya, berasal dari akar kata amma - yaummu - amman, artinya "menuju", "menjadi", "ikutan", "gerak", "jalan besar", dan "maksud" (Lois Ma'luf, 1986: 17).

Makna generik ummah, menurut Ali Syari'ati, setelah membandingkannya dengan istilah qaum, qabâ'il, sya'b, thâifah, dan jamâ'ah ternyata memiliki keunggulan isi, yakni bermakna kemanusiaan yang dinamis. Ummah menurutnya berasal dari kata amma artinya bermaksud (qashada) dan berniat keras (azima). Pengertian ini memuat tiga makna: yaitu "gerakan", "tujuan", dan "ketetapan hati yang sadar" (Ali Syari'ati, 1989: 50). Istilah tersebut mengandung beberapa makna, yakni: kebersamaan dalam arah dan tujuan, konsep gerakan menuju arah dan tujuan tersebut, serta konsep keharusan adanya pimpinan dan petunjuk kolektif. Ummah bagi Syari'ati adalah kumpulan manusia yang para anggotanya memiliki tujuan yang sama, satu sama lain bahu membahu, bergerak menuju cita-cita bersama, berdasarkan kepemimpinan bersama (Abdul Baqy, 1364: 74). Dan ummah di sini tercantum dalam al-Qur'an, dibahas sebagai materi pendidikan kemasyarakatan, sebagai kajian tematik (madhu'iy)

Al-Qur'an menyebutkan kata-kata ummah sebanyak 49 kali yang terdapat dalam 23 surat, sedangkan kata-kata umam sebanyak 11 kali, dalam 9 surat (Abdul Baqy, 1364: 30). Penggunaan kedua kata tersebut dalam al-Qur'an, tidak menunjuk kata tunggal. Ummah adalah konsep yang komprehensif dan mengandung sejumlah makna yaitu;

Pertama, bermakna binatang yang ada di bumi atau burung yang terbang dengan kedua sayapnya, seperti dalam ayat;

Dan tidak ada seekor binatang pun yang ada di bumi dan burung-burung yang terbang dengan kedua sayapnya, melainkan semuanya merupakan umat-umat (juga) seperti kamu. Tidak ada sesuatu pun yang Kami luputkan di dalam Kitab, kemudian kepada Tuban mereka dikumpulkan. (QS. al-An'âm [6]: 38 ).

Kedua, bermakna makhluk Jin, seperti dalam ayat;

Mereka itulah orang-orang yang telah pasti ketetapan (azab) atas mereka bersama umat-umat yang telab berlalu sebelum mereka dari jin dan manusia. Sesunggubnya mereka adalah orang-orang yang merugi (Q.S al-Ahqâf [48]: 18).

Ketiga, bermakna waktu, seperti dalam ayat;

"Dan berkatalah orang yang selamat diantara mereka berdua dan teringat (kepada Yusuf) sesudah beberapa waktu lamanya: "Aku akan memberitakan kepadamu 
tentang (orang yang pandai) mena'birkan mimpi itu, Maka utuslab aku (kepadanya)." (QS. Yusuf [12]: 45).

Keempat, bermakna imam, misalnya dalam surat al Nahl [16]: 120 yang berbunyi:

Sesunggubnya Ibrabim adalah seorang imam yang dapat dijadikan teladan lagi patuh kepada Allah dan hanif dan sekali-kali bukanlah Dia Termasuk orang-orang yang mempersekutukan (Tuhan) (QS. al-Nahl [16]: 120).

Kelima, bermakna agama seperti; dalam surat al-Anbiya' [21]: 92 dan al Mukminun 23: 52 yang berbunyi :

Sungguh, (agama tauhid) inilah agama kamu, agama yang satu, dan Aku adalah

Tuhanmu, maka sembahlah Aku. Dan sungguh, (agama taubid) inilah agama kamu, agama yang satu dan Aku adalah Tuhanmu, maka bertakwalah kepada-Ku (QS. al-Anbiya' [21]: 92).

Penggunaan kata ummah/umam dalam al-Qur'an yang khusus ditujukan kepada manusia dan mengandung beberapa pengertian, antara lain: Pertama, dalam setiap generasi di utus seorang Nabi atau Rasul, di antaranya dapat dilihat dalam surat al Nahl [16]: 36, yang berbunyi:

Dan sungguh Kami telah mengutus seorang Rasul untuk setiap umat (untuk menyerukan),"Sembahlah Allah, dan jaubilah Tagut",kemudian di antara mereka ada yang diberi petunjuk oleh Allah dan ada pula tetap dalam kesesatan. Maka berjalanlah kamu di bumi dan perhatikanlah bagaimana kesudahan orang yang mendustakan (rasul-rasul).

Kedua, bermakna sebagai golongan manusia yang menganut agama tertentu, seperti pada ayat berikut;

Kamu (umat Islam) adalah umat terbaik yang dilabirkan untuk manusia, (karena kamu) menyurub (berbuat) yang makruf, dan mencegah dari yang mungkar, dan beriman kepada Allah. Sekiranya Abli Kitab beriman, tentulab itu lebih baik bagi mereka. Di antara mereka ada yang beriman, namun kebanyakan mereka adalah orang-orang fasik (QS. Ali-Imran [3]: 110).

Setelah menjelaskan kewajiban berdakwah atas umat Islam pada ayat 104, mereka dituntut membentuk persatuan dan kesatuan yaitu pada ayat 103 dan 105, dan berikutnya pada ayat 110 dikemukakan bahwa kewajiban dan tuntutan itu pada hakikatnya lahir dari kedudukan umat Islam sebagai sebaik-baik umat. Ayat ini menjelaskan bahwa seluruh umat Muhammad Saw dari generasi ke generasi berikutnya, adalah umat yang terbaik, karena adanya sifat-sifat yang menghiasi dirinya, yaitu menyuruh kepada yang ma'rûf (apa yang dinilai baik oleh masyarakat selama itu sejalan dengan nilai-nilai Ilâhiyah), dan mencegah yang mungkar (yang bertentangan nilai-nilai luhur), dan beriman kepada Allah dengan iman yang benar. 
Kata ummah mengandung arti gerak dinamis, arah, waktu, jalan yang jelas, dan gaya serta cara hidup. Untuk menuju ke satu arah manusia harus menempuh jalan yang jelas arahnya, serta seseorang harus bergerak maju dengan gaya dan cara tertentu, dan dalam saat yang sama membutuhkan waktu tertentu pula untuk mencapainya (QS. Yusuf [12]: 45). Ummah dapat diartikan dengan waktu, sedangkan (QS. Al Zukhruf [43]: 22) dalam arti jalan ia bermakna gaya dan cara hidup. Dengan demikian, ayat ini menyebutkan tiga syarat yang harus dipenuhi untuk meraih kedudukan sebagai sebaik-baik umat, yaitu amar ma'ruf, nabi mungkar dan persatuan yang berpegang teguh pada agama Allah (iman) (Quraish Shihab, 2000: 173). Menurut al-Maraghy (1986: 49), amar ma'ruf nabi mungkar, penyebutannya didahulukan dari iman kepada Allah, sebab amar ma'ruf-nahi mungkar merupakan pintu dan yang memelihara keimanan. Kebaikan umat ini tidak akan bisa tetap (terbukti) tanpa kehendak untuk memelihara tiga pokok kehidupan tersebut. Bila meninggalkannya, berarti hilanglah keistimewaan umat ini (khairu ummah). Dengan kata lain, ayat ini menyebutkan model masyarakat terbaik (khairu ummah). Ciri utama masyarakat terbaik itu adalah terdapatnya mekanisme kelembagaan maupun non-kelembagaan untuk amar ma'ruf -nabi mungkar serta penduduknya beriman.

Ketiga, bermakna seluruh manusia adalah umat yang satu, misalnya, dalam surat al-Baqarah [2]: 213; Manusia itu adalah umat yang satu. (Setelah timbul perselisiban), maka Allah mengutus para Nabi, sebagai pemberi kabar gembira dan pemberi peringatan.

Keempat, bermakna bagian dari masyarakat yang mengemban fungsi tertentu, yakni menyelenggarakan keutamaan dengan menegakkan yang baik dan mencegah yang munkar. Ini terlihat dalam ayat; "Dan hendaklah ada di antara segolongan kamu umat yang menyeru kepada kebajikan, menyuruh kepada yang ma'ruf dan mencegah kepada yang munkar, merekalah orang-orang yang beruntung." (Q.S Ali Imran [3]: 104).

Dalam tafsirnya, al-Maraghy (1986: 33) menjelaskan bahwa ayat sebelumnya Allah SWT memerintahkan kaum mukmin untuk menyempurnakan jiwa dan membersihkannya dari kotor dan najis yang mengeruhkannya, dengan beramal, bertakwa kapada Allah hingga mati, serta berpegang teguh pada kitabNya dengan mengikuti ajaran-Nya, dan berjalan pada sunnah Rasul-Nya di saat hawa nafsu menguasai mereka, dan pendapat-pendapat saling bertentangan.

Dalam ayat 104, Allah memerintahkan umat Islam agar melakukan penyempurnaan terhadap umat selain mereka, yaitu anggota-anggota umat dan menghimbau agar mengikuti perintah-perintah syari’at serta meninggalkan larangan-Nya, sebagai upaya demi terpeliharanya hukum-hukum syari'at dan dalam rangka memelihara syari'at serta undang-undang. Hendaknya, dalam jiwa anggota umat tertanam cinta kebaikan dan berpegang teguh padanya, yang di dalamnya terkandung kemaslahatan, seolah sama dengan cinta terhadap kemaslahatan pribadi. Dengan demikian, tercipta suatu ikatan yang kuat dan menghimpun mereka dalam mencari kebaikan untuk mereka. Sehingga, menjadi 
umat yang seolah-olah satu tubuh, sebagaimana dikemukakan oleh sebuah hadits, yang berarti; "Perumpamaan orang-orang mukmin dalam kecintaan, kasih sayang, dan kerukunan mereka adalah bagaikean satu tubuh, yakni, bila salah satu organnya sakit, sakitlah seluruh tubuhnya, sehingga membuatnya demam dan tak nyenyak tidur (HR Muslim). Pada hadis lain, misalnya riwayat Imam Bukhari dinyatakan: Orang muk.min terhadap muk.min lainnya bagaikan satu bangunan utub (komponen) dengan (komponen) lainnya saling mengikat."

Dalam ayat di atas ummah merupakan sebuah entitas yang memiliki karakter etis, berupa kecenderungan kepada sifat-sifat utama (khair). Entitas itu memiliki fungsi dan tugas profetik-transformatif, yakni menyeru kepada kebajikan, (ilal khair), menyuruh kepada yang makruf (amar makruf) dan mencegah kamungkaran (nabi mungkar). Ummah yang dimaksud dalam ayat ini adalah sekelompok tertentu dalam masyarakat, bisa berupa organisasi, pemerintah, atau Negara, sebagai bagian dari masyarakat.

Oleh karena itu, lanjut al-Maraghy (1986: 35), dalam melaksanakan dakwah, wajib baginya memenuhi syarat-syarat agar dapat melaksanakan kewajibannya dengan sebaik-baiknya, dan bisa menjadi contoh kesalehan serta menjadi panutan dalam ilmu dan amalnya. Karena itu yang bisa melaksanakan dakwah hanyalah kalangan khusus dari umat Islam, yaitu orang yang mengetahui rahasia-rahasia hukum, hikmah tasyri' dan fiqhnya, seperti yang disyaratkan oleh QS. al-Taubah [9]: 122.

"Mengapa sebagian dari setiap golongan di antara mereka tidak pergi untuk memperdalam pengetabuan agama mereka dan untuk memberi peringatan kepada kaumnya apabila mereka telah kembali, agar mereka dapat menjaga dirinya."

Dengan makna jenis keempat ini, ummah dalam al-Qur'an dibedakan dengan qaum (Al-Baqy: 739-746). Ummah lebih khusus dari pada qaum. Hal ini dapat dilihat dalam al-Qur'an surat al-A'raf [7]: 159.

"Dan di antara kaum Musa itu terdapat suatu ummat yang memberi petunjuk (kepada manusia) dengan (dasar) kebenaran dan dengan itu (pula) mereka berlaku adil menjalankan keadilan."

Dari beberapa ayat di atas, diketahui bahwa penggunaan kata ummah bukan semata entitas beku yang tersatukan oleh perekat tertentu. Ummah adalah komunitas yang memiliki visi etis, profetik dan transformatif. Oleh karena itu, ummah adalah konsep kunci untuk mengetahui tatanan ideal sosok masyarakat menurut Islam (al-Qur'an).

Ummah sebagaimana dijelaskan ayat di atas adalah unit normatif, maka konsep ummah wahidah sebagaimana dalam QS. al-Anbiya' [21]: 92 dan alMukminun [23]: 52, mempunyai sistem nilai yang sama yaitu umat itu satu dalam agama yaitu agama tauhid.

Konsep normatif ummah punya signifikansi dialektis tersendiri bila dihadapkan dengan relitas ummah pada tingkat empirik. Bila tingkat normatif ummah terdiri atas usrah, qaryah, dan jama'ah, maka pada tingkat empirik ummah 
terdiri atas berbagai kelas sosial, kelompok kepentingan dan golongan sosial yang sangat mungkin terjadi benturan satu sama lain.

Masing-masing kelompok sosial harus bekerja sama sebagai satu ummah untuk mewujudkan cita-cita normatif yang sama seperti persamaan dan keadilan. Tekanan pada terwujudnya integrasi, terpeliharanya kohesi sosial dan terhindarnya disintegrasi serta konflik internal yang demikian itu juga dipertegas dalam surat Ali Imran berikutnya, yaitu ayat 105 yang melarang perselisihan intern ummah setelah diperoleh keterangan yang jelas;

"Dan janganlah kamu menjadi seperti orang-orang yang bercerai berai dan berselisih setelah sampai kepada mereka kerangan yang jelas. Dan mereka itulah orang-orang yang mendapat azab yang berat."

Dalam tafsir Al-Mishbah, Quraish Shihab menjelaskan (2004: 166), bahwa sebenarnya ayat-ayat ini bermaksud menyatakan bahwa orang-orang beriman dan bersatu padu akan beruntung dan memperoleh nikmat duniawi dan ukhrawi. Pada ayat sebelumnya yaitu QS. Ali Imaran [3]: 102-103 menunjukkan bahwa orang-orang yang sesat lagi berselisih akan celaka dan mendapat siksa di dunia dan di akhirat. Dari ayat tersebut dapat diketahui betapa indahnya konsep ummah dalam semangat kinerjanya, yakni semangat mampu mengatur diri sendiri dengan mengedepankan kemampuan diri sendiri untuk menyelesaikan persoalan internalnya. Untuk memperkokoh model masyarakat mandiri ini al-Qur'an telah menyediakan mekanisme damai dalam menyelesaikan problem, yaitu melalui; (1) musyawarah (syûra), dalam QS. Ali Imran [3]: 159 atau QS. al-Syura [26]: 58; (2) rekonsiliasi (ishlâh), dalam QS. al-Hujurat [49]: 9, dan (3) seruan dengan kebijaksanaan serta perundingan dengan cara yang lebih baik (da'wah bi al-hikmah wa al-mujâdalah bi al-lati hiya ahsan) dalam QS. al-Nahl [16]: 125.

Selain al-Qur'an memakai ungkapan ummah wahidah, khairu ummah, juga memakai ungkapan ummah wasath, dan ummah muqtashidah. Dalam surat al Baqarah [2]: 143 misalnya masyarakat Islam memperoleh predikat ummah wasath (masyarakat pertengahan atau masyarakat berimbang);

Dan demikian pula Kami telah menjadikan kamu (umat Islam) "umat pertengahan" agar kamu menjadi saksi atas (perbuatan) manusia dan agar Rasul (Mubammad) menjadi saksi atas (perbuatan) kamu...

Melalui bukunya, Wawasan Islam, Quraish Shihab (2004: 347) menjelaskan bahwa, mulanya, kata wasath berarti segala yang baik sesuai dengan objeknya. Sesuatu yang baik berada pada posisi di antara dua ekstrem. Keberanian adalah pertengahan sifat ceroboh dan takut. Kedermawanan merupakan pertengahan antara sikap boros dan kikir. Kesucian merupakan pertengahan antara kedurhakaan karena dorongan nafsu yang mengebu dan impotensi. Dari sini kata wasath berkembang maknanya menjadi tengah. Menghadapi dua pihak berseteru dituntut untuk menjadi wasith (wasit) dan berada pada posisi tengah agar berlaku adil. Di sini lahirlah makna ketiga wasath, yaitu adil. 
Ummatan wasathan adalah umat moderat, yang posisinya berada di tengah, agar dilihat oleh semua pihak, dan dari segenap penjuru. Mereka dijadikan demikian, menurut lanjutan ayat di atas, agar mereka menjadi syuhada' (saksi), sekaligus menjadi teladan dan patron bagi yang lain, pada saat yang sama mereka menjadikan Nabi Muhammad SAW sebagai patron teladan dan saksi pembenaran bagi semua aktifitasnya. Keberadaan umat Islam dalam posisi tengah menyebabkan mereka tidak seperti umat yang hanyut oleh materialisme, tidak pula mengantarnya membumbung tinggi ke alam ruhani dan jasmani, material dan spiritual dalam segala sikap dan aktivitas.

Wasathiyat (moderasi atau posisi tengah) mengundang umat Islam untuk berinteraksi, berdialog, dan terbuka dengan semua pihak (agama, budaya, dan peradaban), karena mereka tidak dapat menjadi saksi maupun berlaku adil jika mereka tertutup atau menutup diri dari lingkungan dan perkembangan global. (Qurais Shihab, 328-329). Selanjutnya, Kuntowijoyo (1997: 4-6) menegaskan, bahwa ummah wasath (posisi tengah), umat Islam tidak hanya sekadar pada tingkat konsep, tetapi juga pada tingkat geografis, sejarah yang aktual, dan pada tingkat budaya. Dalam al-Qur'an Surat al-Maidah [5]: 66, terdapat ungkapan ummah muqtashidah;

"Dan sekiranya mereka sunggub-sunggub menjalankan (bukum) Taurat, Injïl dan (al-Qur'an) yang diturunkan kepada mereka dari Tubannya, niscaya mereka akan mendapat makanan dari atas mereka dan daribawah kaki mereka. Di antara mereka ada sekelompok yang jujur dan taat. Dan banyak di antara mereka sangat buruk apa yang mereka kerjakan."

Sasaran ungkapan ummah muqtashidah dalam ayat di atas, jelas bukan untuk kalangan umat Islam sebagaimana ungkapan yang lain. Kata minhum di atas merujuk kepada ahli kitab. Dengan demikian maksudnya adalah entitas tertentu di kalangan ahli kitab. Dan posisi ummah di situ adalah minoritas, ini terbaca dalam ungkapan berikutnya yang berbunyi wa katsirun minhum sâ'a ma ya'malun.

Kata muqtashid berasal kata iqtashada-yaqtashidu-iqtishad berarti: hemat, tidak pelit, dan tidak boros. Juga berarti i'tidal yakni lurus, sedang, pertengahan, atau sederhana. Ummah muqtashidah adalah kelompok kecil dalam masyarakat yang tetap setia menebarkan kebaikan dan perbaikan serta meminimalisir kerusakan. Ummah muqtashidah, adalah orang yang berlaku jujur dan lurus dan tidak menyimpang dari kebenaran. Oleh karena itulah Allah akan melimpahkan rahmat-Nya dari langit dengan menurunkan hujan, dan menimbulkan rahmatNya dari bumi dengan menumbuhkan tumbuh-tumbuhan yang buahnya melimpah ruah (Ash Shiddiqy dkk. tt: 171).

\section{Implementasi Pendidikan Kemasyarakatan Menurut Al-Qurān}

Al-Qur'an al-Karim menggunakan kalimat-kalimat yang menyentuh hati untuk mengarahkan manusia kepada ide yang dikehendaki-Nya. Dalam mengarahkan pendidikannya kepada manusia, al-Qur'an memandang, menghadapi, memperlakukan makhluk yang namanya manusia sejalan dengan 
unsur penciptaannya, menjadi yang seutuhnya. Karena itu materi-materi pendidikan yang disajikan al-Qur'an hampir selalu mengarah kepada jiwa, akal, dan raga manusia.

Dalam penyajian materi pendidikan yang berhubungan dengan hidup bersama atau bermasyarakat, sebagai suatu umat yang sangat penting keberadaannya dalam mencapai tujuan hidup yang sesungguhnya, yaitu menjadi manusia yang takwa, mendapat forsi yang cukup banyak dalam al-Qur'an. Hal ini terlihat pada konsep kemasyarakatan yang ditemui dalam al-Qur'an.

Penyajian materi pendidikan dalam surat Ali Imran ayat 110 tentang gelar yang diberikan Allah, yaitu "umat terbaik" (khairu ummah) sebagai konsep masyarakat dalam al-Qur'an. Siapa yang memperoleh gelar tersebut? Apa materi pendidikannya, serta bagaimana dalam proses, metode dan tujuannya, serta bagaimana penerapannya? Secara global al-Qur'an telah memaparkannya. Di sinilah pentingnya al-Qur'an perlu dipelajari secara mendalam.

Materinya: Kamu seluruh umat Muhammad adalah umat yang terbaik, karena adanya sifat-sifat yang menghiasi dirinya yaitu umat yang terus-menerus tanpa bosan 1) menyuruh kepada yang makruf, 2) mencegah dari yang mungkar, dan 3) beriman kepada Allah SWT. Tiga tugas ini direspons oleh manusia sebagai peserta didiknya, di mana ada yang beriman dan ada yang fasik. Dihubungkan dengan ayat sebelumnya, ayat 102-105, materinya adalah: mengajak orang beriman untuk; 1) bertakwa kepada Allah dengan sesungguhnya, dan jangan sesaatpun meninggalkan agama hingga mati; 2) bersatu padu dengan agama Allah dan jangan bercerai berai; 3) ingat nikmat Allah kapadamu, ketika kamu bermusuhan, kamu berada di tepi jurang neraka (hidup tanpa bimbingan wahyu), lalu Allah menyelamatkan kamu (dengan kedatangan Islam); 4) agar berupaya mendapat petunjuk secara terus-menerus 5) mengupayakan agar ada suatu kelompok khusus yang menangani dakwah (pendidikan), yakni; (a) mengajak orang lain secara terus-menerus tanpa bosan dan lelah kepada kebajikan (petunjuk-petunjuk Ilahi); (b) menyuruh masyarakat agar mengerjakan hal-hal yang makruf (nilai-nilai luhur serta adat istiadat yang diakui masyarakat), (c) mencegah mereka dari yang mungkar (yang dinilai buruk dan diingkari oleh akal sehat masyarakat); 6) menjadikan mereka sebagai orang yang beruntung yang mengindahkan tuntunan ini serta sungguh lebih bermartabat kedudukannya; 7) dan jangan seperti orang-orang yang berkelompok-kelompok dan berselisih sesudah datang keterangan yang jelas; 8) dan mereka itulah orangorang yang mendapat siksa.

Memperhatikan materi yang disajikan al-Qur'an pada ayat di atas, dapat dipahami bahwa mendapatkan gelar khairu ummah itu harus melalui usaha yang baik dan profesional. Demikian pula sebagai pendidik atau da'i, ditemukan ada tiga syarat yang harus dipenuhi untuk meraih kedudukan sebagai sebaik-baik umat (khairu ummah), yaitu amar makruf, nahi mungkar dan persatuan dalam berpegang teguh pada ajaran Allah. 
1. Tujuan pendidikan yang diharapkan adalah agar memperoleh petunjuk, kemenangan (falâh), dan terhindar dari siksa. Mereka yang memperhatikan dan mengikuti tuntunan niscaya memperoleh petunjuk. Mereka adalah umat yang beriman dan bersatu padu memperoleh kemenangan, sedang mereka yang fasik memperoleh siksa (azab).

2. Metode yang digunakan agar tidak terjadi benturan dalam pelaksanaan tugas, telah diantisipasi dengan dikemukakannya sejumlah pembuktian atau argumentasi (ketika masa jahiliyah, hidup bermusuhan dan Allah mempersatukannya). Melalui kisah-kisah, orang yang bercerai-berai, mendapat siksa sedangkan mereka yang bersaudara memperoleh nikmat lagi kebahagiaan baik dengan metode hikmah, mau'izhah, mujâdalah, syûra maupun ishlâh.

3. Pendidik hendaknya bertugas dengan sebaik mungkin. Seorang pendidik harus dapat menjadi panutan dalam bidang; ilmu, amal, mengetahui hukum, hikmah dan fikih.

4. Peserta didiknya adalah manusia seluruhnya, baik secara individu maupun kelompok. Namun berkelompok itu sangat dibutuhkan untuk mencapai kemajuan dengan cara kebersamaan, bersatu padu, sehingga umat menjadi kuat. Dengan bersama-sama atau berkelompok membentuk suatu organisasi, pendidikan akan lebih baik dan berkualitas, dan sebagai makhluk sosial dan berbudaya, hal ini sudah semestinya ada sebagaimana perintah Allah tersebut.

Tujuan yang ingin dicapai oleh al-Qur'an adalah membina manusia guna mampu menjalankan fungsinya sebagai hamba Allah dan khalifah-Nya. Pembinaan akalnya menghasilkan ilmu, pembinaan jiwanya menghasilkan kesucian dan etika, sedang pembinaan jasmani menghasilkan sederet keterampilan. Dengan penggabungan unsur-unsur tersebut maka terciptalah makhluk dwi dimensi dalam satu keseimbangan yaitu; dunia dan akhirat, ilmu dan iman.

Pendidikan harus dilaksanakan secara terus-menerus, karena keselamatan dan kekuatan masyarakat tergantung pada keselamatan individu dan kesiapannya. Untuk itu Islam sangat memperhatikan pendidikan anak-anak, baik pendidikan sosial maupun pendidikan akhlaknya atau perilakunya. Apabila mereka telah terdidik, terbentuk dan bergelut di dalam kehidupannya maka mereka akan memberikan gambaran yang benar tentang manusia yang cakap, seimbang, berakal, dan bijaksana, di manapun ia berada.

Para pendidik harus berusaha keras, penuh dedikasi untuk melaksanakan tanggung jawabnya dengan sebaik-baiknya dalam pendidikan kemasyarakatan sehingga pendidik dapat memberikan andil di dalam membina suatu masyarakat Islami yang utama dan berpusat pada keimanan, akhlak dan sosial yang terbaik, dan norma-norma Islam yang tinggi. Semua ini bagi Allah sebagai pendidik yang 
Maha Agung, tidak sulit untuk mewujudkannya, namun Allah ingin menguji hamba-Nya.

Metode praktis yang dapat dipergunakan di dalam pedidikan kemasyarakatan menurut Nashih Ulwan (1988: 391-571) adalah penanaman dasar-dasar psikis yang mulia, seperti takwa, persaudaraan, kasih sayang, mengutamakan orang lain, pemberian maaf dan keberanian. Tujuannya;

1. Pemeliharaan hak-hak orang lain, seperti hak tehadap orang tua, hak terhadap saudara-saudara, hak terhadap guru, hak terhadap teman dan hak terhadap orang besar

2. Pelaksanaan tata kesopanan, seperti: adab makan dan minum, adap memberi salam, adab meminta izin, adab di dalam majlis, adab berbicara, adab bergurau, adab mengucapkan selamat, adab menjenguk orang sakit, adab berta'ziyah, serta adab bersin dan menguap.

3. Pengawasan dan kritik sosial, seperti: memelihara pendapat umum, dasar-dasar yang berlaku dalam pemeliharaan tersebut, selalu mengingat sikap-sikap para Salaf.

Dalam konteks Indonesia implementasi pendidikan kemasyarakatan yang khas Islam terlembagakan dalam pesantren. Sebagai lembaga pendidikan yang paling tua dan khas Indonesia, kontribusi pesantren kepada masyarakat dan bangsa masih relevan dan diperlukan. Penelitian Naim menunjukkan bahwa ada tiga karakter dasar yang memungkinkan pesantren memberi kontribusi besar dalam mengembangkan pendidikan kemasyarakatan (sosial) dan kebudayaan yaitu; 1) pesantren merupakan lembaga pendidikan Islam yang paling terpadu (tabligh) dengan masyarakat. Pesantren tidak pernah menentukan secara ketat sistem penerimaan santrinya. Artinya pesantren adalah milik masyarakat, karena itu masyarakat secara terbuka dan sukarela menitipkan anaknya kepada kiai; 2) sistem pembelajaran melibtkan santri selama 24 jam karena tinggal dalam satu pemondokan yang sama. Kondisi ini memungkinkan kiai dan santri berinterkasi dalam keteladan secara intensi pula; 3) karakter pembelajaran di pesantren memungkinkan ditafsirkan dalam konteks sosial dan kebudayaan. Menurutnya Islam juga memiliki 3 fungsi sekaligus yaitu mitis (tauhid), ontologis (olah pikir/ilmu) dan fungsional (membangun peradaban). Ketiga fungsi ini, secara sinergis dan strategis dapat memosisikan pesantren sebagai lembaga yang mengemban misi mendidikkan karakter sosial (ummat) warga dan bangsa Indonesia (Naim, 2012: 446).

\section{SIMPULAN}

Menegakkan masyarakat yang adil berdasarkan etika, merupakan tujuan utama al-Qur'an. Oleh karena itu, pendidikan kemasyarakan mutlak diperlukan. Secara fitri manusia itu bersifat kemasyarakatan, karena setiap orang tentu hidup dalam suatu kelompok yang diikat oleh berbagai aturan (agama). Ciri-ciri masyarakat Islam itu adalah masyarakat yang menerapkan Islam dalam berbagai aspeknya dalam kehidupan individu dan bersama, dan makhluk lainnya. Al- 
Qur'an memberikan pengertian bahwa kemasyarakatan itu dapat dilihat pada istilah yang berhubungan dengan suatu gejala tertentu kemasyarakatan, sedang yang lain istilahnya digunakan hanya untuk menggambarkan jenis perilaku. Konsep ummah mempunyai keunggulan muatan makna, kemanusiaan yang dinamis, yaitu bermakna binatang, waktu, makhluk jin, iman dan agama. Sedangkan penggunaan kata ummah khusus ditujukan kepada manusia mengandung makna generasi, golongan manusia, seluruh manusia, dan bermakna bagian dari masyarakat. Predikat ummah yang ditemukan dalam alQur'an adalah ummah wahidah, khairu ummah, ummah wasatha, ummah muqtashida. Penerapan materi pendidikan kemasyarakatan menurut al-Qur'an, sangat sistematis, menyeluruh dan menyentuh semua dimensi, mempergunakan metode yang relevan dan aktual, menggunakan argumentasai yang kentekstual, mempunyai tujuan yang jelas.

\section{DAFTAR PUSTAKA}

Al Maraghy , Ahamad Mustafa. 1986. Tafsir Al Maraghy, terjemahan: Burhan Abu Bakar dan Herri Noer Ali, Semarang: Toha Putra.

Al Munawwir, Ahmad Warson. 1984. Al Munawnir Kamus Arab-Indonesia, Surabaya: Pustaka Progresif.

Al-Faruqi, Ismail R. 1993. Islam dan Kebudayaan, terjemahan Yustiono, judul asli: Islam and Culture, Bandung: Mizan.

Al-Syaibany, Al-Tomy Muhammad Omar. 1975. Falsafah Pendidikan Islam, terjemahan: Hasan Langgulung, Judul asli: Falsafah Al Tarbiyah Al Islamiyah, Jakarta: Bulan Bintang.

Ansari, Rahman Muhammad Fazlur. 1983. Konsep Masyarakat Islam Modern, terjemahan: Juniarso, judul asli: The Quranic Fundation and Structure of Muslim, Society, Bandung: Risalah.

Ash Shiddiqy, Hasbi, dkk. tt. Penerjemah/Pentafsir al-Qur'an, al-Qur'an dan Terjemahnya, Hadiah dari Khadim al Haramaini Asy-Syarifain (Pelayan kedua Tanah Suci) Raja Fahd ibn 'Abd al 'Aziz Al Sa'ud.

Baqy, Abdul Fuad Muhammad. 1945. Al-Mu’jam Li al-faz̧hi al-Qurān al-Karim, Mesir; Daar al Kitab.

Fayed, Abdul Wahab Muhammad Syekh. 1989. Pendidikan Dalam Al-Qurān, terjemahan: Judi Al Falasany, Judul asli: Al Tarbiyah Fi al Kitabillah, Semarang: Wicaksana.

Kuntowijoyo.1997. Identitas Politik. Muslim, Bandung: Mizan.

Kusumamihardja, Supan dkk. 1995. Studia Islamica, Jakarta: Girimukti Pasaka, 1985. Soerjono Soekanto, Sosiologi Suatu Pengantar, cet. Ke 21, Jakarta: Raja Grafindo Persada.

Ma'luf, Lois. 1997. Al Munjid fi al Lughat wa al 'Alam, Beirut: Dar al Masyriq.

Muthahhari, Murtadha. 1992. Masyarakat dan Sejarah, terjemahan M.Hashem, judul asli: Society and History, Bandung: Mizan. 
Muthahhari, Murtadha. 1992. Masyarakat Dan Sejarah, terjemahan: M.Hashem, judul asli: Society and History, Bandung: Mizan.

Naim, Ngainum, 2012. Mengembalikan Misi Pendidikan Sosial Dan Kebudayaan Pesantren. Media Pendidikan Jurnal Pendidikan Islam. Volume XXVII Nomor 3.

Nashih Ulwan, Abdullah. 1988. Pedoman Pendidikan Anak Dalam Islam, terjemahan: Saifullah Kamalie dan Hery Noer Ali, judul asli: Tarbiyatu al Aulad fi al Islam, Bandung: Asy-Syifa'.

Pulungan, J.Suyuti. 1994. Prinsip-Prinsip Pemerintah dalam Piagam Madinah Ditinjau dari Pandangan al-Qurān, Jakarta: Raja Grafindo Persada.

Saleh Abdullah, Abdurrahman. 1990. Teori-Teori Pendidikan Bardasarkan al-Qurān, terjemahan Arifin M.Ed., judul asli: Educational Theory: Quranic Outlook, Jakarta: Rineka Cipta. Soejono, Ag. 1980. Pendabuluan Ilmu Pendidikan Umum, Bandung: CV. Ilmu.

Shihab, Quraish. 1994. Membumikan A, Qur'an- Fungsi dan Peran Wabyu Dalam Kehidupan Masyarakat, Bandung: Mizan.

Shihab, Quraish. 2000. Wawasan Islam Tafsir Maudhu'I atas Pelbagai Persoalan Umat, Bandung: Mizan, cet. X.

Shihab, Quraish. 2004. Tafsir Al-Mishbah Pesan, Kesan dan Keserasian Al-Qurān, Volume 2, Jakarta: Lentera Hati.

Syari'ati, Ali. 1989. Ummah dan Imamah Suatu Tinjauan Sosiologis, Bandung: Pustaka Hidayah.

Tim Penyusun Pusat Pembinaan dan Pengembangan Bahasa. 1999. Kamus Besar Bahasa Isdonesia, Departemen Pendidikan dan Kebudayaan, Jakarta: Balai Pustaka. 